\title{
VILAÇA, Aparecida. 2020. Morte na Floresta. São Paulo: Editora Todavia. 56 p.
}

\author{
CAROLINE LEONARDI DE QUADROS
}

UNIVERSIDADE FEDERAL DO PARANÁ (UFPR), CURITIBA/PR, BRASIL

HTTPS://ORCID.ORG/OOOO-0002-8I8I-5388

O ano de 2020 ficará marcado pelo advento da pandemia do Covid-19, uma doença causada por um vírus do tipo corona que, em decorrência da relação predatória de humanos para com não humanos, tornou-se uma afecção altamente contagiosa entre nós. A quantidade de vítimas que contabiliza em diversos países definitivamente assusta. No Brasil, em meio ao negacionismo - inclusive por parte de governantes -, o vírus encontrou um local favorito para se disseminar, já que não pode ocorrer a devida adoção de medidas de proteção mundialmente reconhecidas como eficazes para diminuir o contágio. $\mathrm{O}$ resguardo em casa, a quarentena, foi possível apenas para alguns grupos de trabalhadores e estudantes; além disso, a medida de restrição à circulação funcionou/funciona de forma muito parcial para prestadores de serviços, para grupos sociais que, desde o início, não tinham local para resguardo e, também, para aqueles que são impossibilitados de realizar seu isolamento. Por isso, entre os números de vítimas fatais, nota-se que o vírus massacra, principalmente, trabalhadoras e trabalhadores pobres, negras e negros e indígenas.

Morte na floresta, escrito pela professora do Museu Nacional (vinculado à Universidade Federal do Rio de Janeiro), Aparecida Vilaça, foi lançado em maio de 2020, poucos meses após o anúncio do surto pandêmico pela Organização Mundial da Saúde, em 11 de março. Nele, a antropóloga expressa a negligência que afeta os povos indígenas brasileiros, tanto nesse como em vários outros momentos epidêmicos e pandêmicos. Dessa forma, o livro apresenta a experiência dos povos indígenas frente ao descaso e desrespeito com a saúde, tendo em vista as particularidades existentes em relação a processos de cura e adoecimento, particularidades essas que, conforme a autora avança nos capítulos, demonstram-se como alvo do aparato colonial.

O livro é organizado em sete capítulos. O primeiro, intitulado "Somos todos indígenas", traça o caminho da Covid-19 nas comunidades indígenas, desde sua chegada até maio de 2020, momento retratado pela autora, em que a doença passara a afetar, principalmente, os povos do Alto Solimóes e do Alto Rio Negro, a oeste de Manaus, no estado do Amazonas. A autora apresenta a ideia de que essa seria a primeira vez em que "nós, os invasores" experienciamos a mesma doença com a mesma vulnerabilidade física, seja pela falta de anticorpos, seja pela inexistência de remédios. Apresentada a ideia, 
que à primeira vista parece inegável, a autora determina os fatores que logo diferenciam as experiências pandêmicas entre indígenas e não indígenas.

Deve-se pontuar, como inicial diferença, a relevância que os falecimentos dos velhos e velhas têm nas comunidades abordadas. São vários os povos, por toda extensão do território brasileiro, que choram essas vidas, por serem os velhos os que possibilitam a continuidade da transmissão de saberes. Outro fator diverso, segundo a autora, se dá pelo descumprimento, por parte das instituições governamentais em franco desmonte, das medidas de fiscalização à preservação do meio ambiente ou das ações de assistência à saúde.

À vista da saúde indígena o descaso se mostra especialmente pela subnotificação dos casos de indígenas acometidos pela Covid-19, principalmente daqueles em contexto urbano, e em momento pré-pandemia, na pulverização por parte de agentes de saúde que comparecem nas comunidades sazonalmente. Essa última condição faz com que casos urgentes ou de gravidade sejam dirigidos a hospitais maiores nas cidades e dessa forma a assistência especial acaba, na medida em que o paciente indígena divide a fila de espera com o não indígena dependente do Sistema Único de Saúde, o SUS. A negligência ao atendimento especial à saúde indígena gerou uma movimentação dos povos, que encontraram, com esforço, uma solução por meio de arrecadações online e construção de barragens sanitárias nas vias que dão acesso às aldeias, para que assim pudessem assegurar isolamento social. Isolamento, esse, que busca dificultar a entrada de um vírus contaminante que ingressa com muita facilidade por meio de agentes dos órgãos de fiscalização e, também, pelos invasores de suas terras, que usaram da atualidade da pandemia como um escudo, ou cortina de fumaça, para ampliar suas ações ilegais.

No segundo capítulo, chamado "Cinco séculos de epidemias", Vilaça traz um cenário cronológico que remete aos contágios de doenças estranhas aos indígenas no século XVI em diante. A partir de um relato sobre a varíola em uma missão jesuíta, a autora demonstra como os missionários curavam o que eles mesmos levavam aos aldeamentos onde ocorria a catequização católica. A antropóloga enfatiza e relembra, pois, o papel das missões religiosas ou frentes de contato para pacificação que, além da atribuição preponderante no esbulho de terras indígenas, também foram determinantes na disseminação de patologias exógenas que adentraram - e hoje continuam a adentrar - os territórios dessas comunidades. São muitas as doenças levadas nos presentes diversos, nos alimentos, nas roupas; objetos e corpos que movimentaram epidemias de gripe, pneumonia, tuberculose, varíola, todas doenças avassaladoras na vida dos povos contatados.

Nesse mesmo capítulo, Vilaça redige relatos sobre a violência e as doenças levadas aos Wari', contatados em 1961, povo indígena com quem trabalha há décadas, além de trazer relatos entre os Yanomami e o transtorno vivenciado com a invasão de garimpeiros em suas terras da década de 1980 até o presente período. As narrativas contêm cenas marcantes que expressam a enorme hostilidade destina$\mathrm{da}$ aos povos indígenas recém-contatados e, com frequência, deslocados compulsoriamente. Também mostram como na agência própria de fugir das doenças alheias, eles acabavam por morrer nas trilhas da floresta em meio a outros corpos adoecidos.

Dado o intuito dos povos indígenas em fugir mato adentro, o terceiro capítulo, "O isolamento social'”, revela o movimento já antigo de resguardo realizado por povos indígenas frente à invasão de 
suas terras e as mazelas que acompanham esse apoderamento. Esse isolamento, assegurado a partir da mobilidade para espaços distantes do avanço dos brancos, é um dos motivos aos quais a autora atribui a sobrevivência de muitos povos. Hoje, em contrapartida a essa prática antiga, são os povos voluntariamente isolados do Sudoeste amazônico que correm maior perigo, por se encontrarem em áreas incertas no cenário legal e constantemente invadidos pelos personagens já recorrentes: mineradores, madeireiros, garimpeiros e missionários religiosos. Com o advento da Covid-19, esses sujeitos propagadores do vírus agem sem preocupações, pois suas ações certamente obterão a aprovação do atual governo.

A este respeito a autora ressalta a nomeação - mais tarde, indeferida - de um missionário evangélico para conduzir a Coordenação Geral de Índios Isolados e Recém-Contatados da Fundação Nacional do Índio (FUNAI). Importante ressaltar que, mesmo com a designação suspensa, a Frente Parlamentar Evangélica conseguiu a aprovação de um projeto de lei que autoriza a entrada de missionários nas áreas indígenas sob a justificativa de dar-lhes assistência; esse dito auxílio, no entanto, não seria necessário caso as comunidades pudessem ter autonomia sobre seu isolamento.

Além dos problemas gerados para os povos isolados ou recém-contatados, a pandemia do novo coronavírus também impacta as comunidades com elevado contato com não indígenas. Essas comunidades, geralmente aldeadas perto de cidades, dependem dos serviços de centros comerciais para assegurar a alimentação e acesso a benefícios governamentais; além disso, grande número desses grupos vive em terras pobres para o plantio e sofre com a impossibilidade da caça e da pesca, o que denota essa dependência. Enquanto algumas comunidades vinham, há tempos, se preparando para estabelecer uma autonomia alimentar a partir de roçados, como é o caso dos Ashaninka no Acre, outros grupos não conseguiram romper esse ciclo de sujeição aos deslocamentos para a cidade. Sendo assim, como Vilaça bem destaca, os caminhos que tomam para a compra de suprimentos e saques de auxílios (seja os oriundos do Programa Bolsa Família ou os do Auxílio Emergencial) os colocam em constante risco.

O capítulo "Espíritos, xamãs e doenças" apresenta, por sua vez, uma reflexão acerca dos agentes patógenos na perspectiva indígena. Esses agentes sempre são alheios, como já fora explicitado, podem ser invasores, mas também, em um entendimento expandido sobre a humanidade, podem ser espíritos de animais, plantas, espíritos dos parentes que já se foram, feitiçaria de humanos. Essa relação com não humanos, salienta Vilaça, é uma das causas da moralidade do cuidado indígena, em que cuidar é evitar que esses agentes busquem gentes para si, sendo que uma das formas de capturar gentes advém do adoecimento e da possibilidade de morte. Cuidar aqui é, portanto, estabelecer proximidade. Entre os Wari', exemplifica a pesquisadora, a pessoa adoentada em casa ou no hospital jamais permanece desacompanhada, assim como jamais é vista como um agente patogênico. Segundo a autora, a pessoa doente vive em um limbo entre o mundo dos vivos e o mundo dos espíritos, e dessa forma a proximidade de parentes vivos serve para recordar à pessoa seu lugar junto a eles. Fazer e continuar parentesco é curar, mesmo com a administração de medicamentos ou com a ideia de domínio das doenças pelos humanos levada pela catequização evangélica. O melhor remédio ainda é a proximidade.

No quinto capítulo, "A civilização viral", Vilaça retorna às críticas e, a partir de uma metáfora, equipara o vírus e toda sua potencialidade de transformar células em réplicas trabalhadoras de si mesmo com a invasão europeia e sua transcrição de comportamentos e formas de viver a tudo que seja 
diverso. No penúltimo capítulo, intitulado "O equívoco de virar branco", a autora demonstra a capacidade de criação através da apropriação, por parte dos índios, de elementos não indígenas, ressaltando interesses opostos aos da característica predatória e viral. Revela, assim, o interesse das comunidades em perceber a alteridade e prezar pela multiplicidade: não há um desejo de virar o outro em definitivo; todavia existe, sim, interesse em boas trocas.

Depois de ter explorado o contínuo descaso em prol da colonialidade e, por outro lado, a resistência e apropriações criativas dos indígenas, Vilaça destaca no sétimo e último capítulo, "Reconectando", como o vírus que perambula pelos corpos tem o papel, ou deveria ter, de recordar o emaranhamento em que estamos entrelaçados, humanos e não humanos. A autora ressalta que na narrativa indígena um elo danificado nesse emaranhado conduz a danos a muitos outros. Sendo assim, a já mencionada relação predatória dos humanos para com não humanos oferece um caminho destrutivo. A perseguição e humilhação advindas de não indígenas em relação às histórias que recontam o perigo dessa predação tornam esse emaranhado invisível. Estando essas histórias ocultas, mais fácil de serem estabelecidas por invasores como marcas da mentira, da crença, da dicotomia do bem e do mal. Essa invisibilidade da conexão nos custa o meio ambiente e, por conseguinte, nossas vidas e o mundo como os conhecemos.

Aparecida Vilaça nos faz rememorar que, mesmo conhecendo as narrativas que alertam para o fim do "mundo como ele é" (a partir da objetificação de seus recursos, do salvamento de pequenos espécimes como exemplares do que fomos e tivemos), a sociedade viral continua a procurar outros locais e outros corpos para replicar seus modos. Mesmo sendo um livro-denúncia, as páginas mostram que esse triste período pode ser um empurrão para mudança. A pandemia não terminou até o momento de escrita dessa resenha, em outubro de 2020; pessoas seguem morrendo, biomas brasileiros estão sendo destruídos pelo fogo criminoso do agronegócio e a fumaça chega às cidades onde as máscaras já dificultavam a respiração. Os povos indígenas, seus xamãs, seus intelectuais e contadores de história seguem a avisar.

Caroline Leonardi de Quadros é Bacharel em Ciências Sociais pela Universidade Federal do Paraná e mestranda em Antropologia e Arqueologia nesta mesma instituição. Bolsista CAPES.

RECEBIDO: $17 / 10 / 2020$

ACEITO: 26/01/2021 